Jurnal Kesehatan Perintis (Perintis's Health Journal) 8 (1) 2021: 45-53

Contents list available at JKP website

Jurnal Kesehatan Perintis (Perintis's Health Journal)

Journal homepage: https://jurnal.stikesperintis.ac.id/index.php/JKP

\title{
Asupan Energi, Asupan Lemak, Aktivitas Fisik Dan Pengetahuan, Berhubungan dengan Gizi Lebih pada Remaja SMA
}

\author{
Rahmita Yanti, Maria Nova*, Aulia Rahmi
}

Jurusan Gizi, FIKES, Universitas Perintis Indonesia, Indonesia

\section{Article Information :}

Submission: May 05, 2021; Revised:Jun 26, 2021; Accepted:Jun 30, 2021; Available online: Jun 30,2021

*Corresponding author : opha1723@gmail.com

\begin{abstract}
ABSTRAK
Masalah overweight dan obesitas penting untuk diperhatikan pada remaja karena $80 \%$ remaja berpeluang mengalami obesitas pada saat dewasa. SMA Pembangunan Kota Padang memiliki prevalensi status gizi lebih tertinggi pada tahun 2017 yaitu 22,52\%. Penelitian ini bertujuan untuk mengetahui hubungan asupan energi, asupan lemak, aktivitas fisik, pengetahuan gizi dan kualitas tidur dengan kejadian gizi lebih pada remaja SMA. Metode penelitian ini menggunakan desain cross sectional study. Variabel independen (asupan energi, asupan lemak, aktivitas fisik, pengetahuan gizi, kualitas tidur) dan variabel dependen (kejadian gizi lebih) dikumpulkan dalam waktu yang bersamaan. Instrumen yang digunakan adalah SQ-FFQ, kuesioner, timbangan berat badan dan microtoise. Populasi sebanyak 389 orang dan sampel 57 orang. Penelitian ini menggunakan uji chi-square pada tingkat kepercayaan 95\%. Hasil penelitian menunjukkan $28.1 \%$ siswa mengalami gizi lebih. Proporsi kejadian gizi lebih banyak ditemukan pada remaja dengan asupan energi berlebih(64.3\%), asupan lemak berlebih(70\%), aktivitas fisik tidak aktif $(47.6 \%)$, pengetahuan gizi cukup (50.0\%), dan kualitas tidur buruk (36.4\%). Hasil uji statistik menunjukkan terdapat hubungan asupan energi, asupan lemak, aktifitas fisik, pengetahuan gizi dengan kejadian gizi lebih $(p<0,05)$, dantidak terdapat hubungan kualitas tidur dengan kejadian gizi lebih ( $p>0.05$ ). Disarankan kepada remaja untuk lebih memperhatikan makanan yang dikonsumsi terutama makanan yang mengandung tinggi energi dan tinggi lemak agar tidak terjadi kenaikan berat badan secara signifikan, aktif melakukan aktivitas fisik, meningkatkan pengetahuan gizi demi mencapai sikap dan tindakan positif dalam memilih makanan yang akan dikonsumsi.
\end{abstract}

Kata Kunci: Gizi lebih, asupan energi, lemak, aktivitas fisik, pengetahuan gizi

\section{ABSTRACT}

The problems of overweight and obesity among adolescents need to be concerned because $80 \%$ of them have the opportunity to be obese when they are adults. SMA Pembangunan Padang got the highest prevalence of overnutrition status at $22.52 \%$ in 2017 . This study aimed to determine the relationship of energy intake, fat intake, physical activity, nutrition knowledge and sleep quality with the occurrence of overnutrition among adolescents of SMA. This study was cross sectional study. Independent variables (energy intake, fat intake, physical activity, nutrition knowledge, sleep quality) and dependent variables (the occurrence 
of overnutrition) were collected at the same time. The instruments were SQ-FFQ, questionnaires, weight scale and microtoise. The population was 389 students and the sample was 57 students. This study used chi-square test at confidence level 95\%. This study revealed that $28.1 \%$ of the students faced overnutrition. The proportion of the occurrence of overnutrition was mostly found among adolescents with excess energy intake (64.3\%), excess fat intake (70\%), inactive physical activity (47.6\%), insufficient nutrition knowledge (50.0\%), and poor sleep quality (36.4\%). The results of Statistic test showed that there was relationship of energy intake, fat intake, physical activity and nutrition knowledge with the occurrence of overnutrition $(p<0.05)$, and that there was no relationship between sleep quality and the occurrence of overnutrition ( $p>0.05)$. It is recommended for adolescents to pay more attention to food consumed especially high-energy and high-fatfood, to actively engage in physical activity, and to enhance nutrition knowledge in order to achieve positive attitudes and actions in choosing food to consume.

\section{Keywords: Overnutrition, energy and fat intake, physical activity, nutrition knowledge}

\section{PENDAHULUAN}

Permasalahan gizi yang terjadi di Indonesia saat ini telah menjadi permasalahan gizi ganda. Masalah gizi kurang belum teratasi, sementara di lain sisi telah muncul masalah gizi lebih. Kondisi ini dapat dialami oleh anak-anak, remaja dan seluruh golongan umur (Almatsier, 2013). Overweight dan obesitas merupakan ketidakseimbangan jumlah asupan yang dikonsumsi dengan kebutuhan, sebagai kondisi asupan kalori lebih banyak dikonsumsi daripada yang dibutuhkan oleh tubuh seseorang (Ermona \& Wirjatmadi, 2018).

Masalah overweight dan obesitas penting untuk diperhatikan pada remaja karena $80 \%$ berpeluang untuk mengalami obesitas pada saat dewasa (S. Wulandari et al., 2016). Masalah overweight dan obesitas merupakan masalah kompleks dan merupakan masalah kesehatan yang sifatnya kronis, menimbulkan masalah kesehatan yang serius dan menyebabkan berbagai penyakit tidak menular (Pakar Gizi Indonesia, 2017). Kejadian ini akan berpotensi menyebabkan gangguan dalam fungsi tubuh, beresiko untuk menderita penyakit seperti diabetes melitus, hipertensi, penyakit jantung koroner, penyakit kanker dan dapat memperpendek harapan hidup (Almatsier, 2013).

Berdasarkan laporan Riskesdas Nasional prevalensi overweight dan obesitas di Indonesia pada remaja usia 16 sampai 18 tahun sebesar $13.5 \%$ pada tahun 2018 (Riskesdas, 2018). Hal ini menunjukkan terjadi peningkatan dibandingkan tahun 2013 sebesar 7.3\% dan di tahun 2010 sebesar 1.4\% (Riskesdas, 2013). Prevalensi overweight dan obesitas pada remaja usia 16-18 tahun di Sumatera Barat tahun 2018 yaitu sebesar 11.5\% (Riskesdas, 2018). Terjadi peningkatan dibandingkan tahun 2013 sebesar 7.5\% (Riskesdas, 2013). Berdasarkan data Dinas Kesehatan Kota Padang tentang status gizi remaja SMA se Kota Padang tahun 2017 diperoleh data prevalensi overweight dan obesitas tertinggi terdapat di SMA Pembangunan Kota Padang yaitu sebesar $22.52 \%$. Dengan jumlah siswa/i hasil penjaringan sebanyak 222 orang, didapatkan 31 orang siswa/i overweight dan 19 orang siswa/i obesitas (DKK, 2018).

Salah satu penyebab gizi lebih yaitu ketidakseimbangan antara asupan energi dan pengeluaran energi dalam jangka waktu yang lama sehingga akan menyebabkan timbunan sebagai lemak yang berlebihan (Ermona \& Wirjatmadi, 2018). Asupan energi yang berlebih berasal dari konsumsi makanan tinggi energi akan disimpan sebagai lemak tubuh (Almatsier, 2013). Penelitian Wulandari, 2015 menunjukkan bahwa terdapat hubungan yang bermakna antara asupan energi dengan kejadian gizi lebih (N. W. M. Wulandari et al., 2015). Penelitian juga menunjukkan bahwa terdapat hubungan yang bermakna antara asupan lemak dengan kejadian gizi lebih, yaitu Asupan lemak dikonsumsi melebihi kebutuhan dalam jangka waktu lama dapat memicu timbulnya masalah gizi lebih (D. T. Wulandari \& Mardiyati, 2017). 
Status gizi lebih juga dapat disebabkan oleh aktifitas fisik yang kurang. berkurangnya aktivitas fisik karena perbaikan ekonomi akan berakibat semakin banyaknya penduduk golongan tertentu mengalami masalah gizi lebih berupa overweight dan obesitas (Almatsier, 2013). Penelitian menunjukkan bahwa terdapat hubungan yang bermakna antara aktivitas fisik dengan status gizi, yaitu status gizi lebih, banyak terdapat pada siswa yang aktivitas fisik ringan (Afrilia \& Festilia, 2018). Sejalan dengan penelitian Ermona, Et, al faktor yang berhubungan dengan kejadian gizi lebih yaitu aktivitas fisik dan asupan gizi (Ermona \& Wirjatmadi, 2018).

Salah satu faktor penentu seseorang dalam memilih makanan yang tepat adalah pengetahuan gizi. Pengetahuan kurang tentang makanan sehat dan gizi seimbang membuat masyarakat cenderung memilih makanan sesuai dengan selera, sosial ekonomi, dan trend sosial yang terjadi di masyarakat (Pakar Gizi Indonesia, 2017). Pengetahuan gizi seseorang akan berpengaruh terhadap sikap dan perilaku untuk pemilihan makanan, keadaan seperti ini akan mempengaruhi status gizi individu (Soraya et al., 2017).

Faktor penyebab Gizi lebih juga dapat dipengaruhi oleh kualitas tidur seseorang, pola tidur yang singkat pada malam hari akan berdampak pada peningkatan berat badan. Kualitas tidur merupakan ukuran seseorang untuk dapat kemudahan dalam memulai tidur dan untuk mempertahankan tidur. Kualitas tidur yang baik akan ditandai dengan tidur yang tenang, merasa segar pada pagi hari, dan merasa semangat untuk melakukan aktivitas (Putra et al., 2017). Penelitian Ryandra 2016 menunjukkan bahwa terdapat hubungan yang signifikan antara kualitas tidur dengan berat badan berlebih (Ryandra, 2016). Sejalan dengan penelitian Marfuah 2015 yaitu terdapat hubungan yang signifikan antara kualitas tidur dengan kejadian gizi lebih, yaitu kualitas tidur yang buruk merupakan faktor resiko terjadinya obesitas. Kualitas tidur yang buruk menyebabkan peningkatan asupan energi yang akan berdampak terhadap gizi lebih (Marfuah, 2015). Beda penelitian ini dengan penelitian sebelumnya adalah penelitian ini melihat propaganda gizi, saru sisi membahas gizi lebih dan gizi kurang. Tujuan penelitian ini untuk mengetahui hubungan asupan energi, asupan lemak, aktivitas fisik, pengetahuan gizi dan kualitas tidur dengan kejadian gizi lebih pada remaja SMA.

\section{METODE PENELITIAN}

Jenis penelitian ini adalah penelitian analitik dengan menggunakan desain cross sectional study. Populasi dalam penelitian ini seluruh siswa kelas $\mathrm{X}$ dan $\mathrm{XI}$ berjumlah 389 siswa dan sampel sebanyak 57 siswa. Teknik pengambilan sampel dengan cara situasional kelas X dan XI mewakili masingmasing satu kelas untuk di jadikan sampel. Data primer pada penelitian ini yaitu data gizi lebih diperoleh dengan mengukut berat badan, tinggi badan dan mengetahui umur remaja, data asupan energi dan asupan lemak wawancara menggunakan form SQ$F F Q$, data aktivitas fisik wawancara menggunakan kuesioner GPAQ, data pengetahuan gizi wawancara menggunakan kuesioner dan data kualitas tidur wawancara menggunakan kuesioner PSQI. Data sekunder data yang di peroleh dari Dinas Kesehatan kota Padang. Pengolahan data editing, coding, entry dan cleaning. Analisis data menggunkan uji chisquare.dengan tingkat kepercayaan (95\%).

\section{HASIL DAN PEMBAHASAN}

Tabel 1. Asupan energi, asupan lemak, pengetahuan gizi, kualitas tidur dan kejadian gizi lebih Di SMA $(n=57)$

\begin{tabular}{lcc}
\hline \multicolumn{1}{c}{ Variabel } & n & $\%$ \\
\hline Asupan Energi & 14 & 24,6 \\
Lebih & 43 & 75,4 \\
Cukup & & \\
$\begin{array}{l}\text { Asupan Lemak } \\
\text { Lebih }\end{array}$ & 10 & 17,5 \\
Cukup & 47 & 82,5 \\
Aktivitas Fisik & & \\
Tidak Aktif & 21 & 36,8 \\
Aktif & 36 & 63,2 \\
Pengetahuan & & \\
Cukup & 16 & 28,1 \\
Baik & 41 & 71,9 \\
Kualitas Tidur & & \\
Buruk & 33 & 57,9 \\
Baik & 24 & 42,1 \\
\hline
\end{tabular}




\begin{tabular}{lll}
\hline Kejadian Gizi Lebih & & \\
Gizi lebih & 16 & 28,1 \\
Tidak gizi lebih & 41 & 71,9 \\
\hline
\end{tabular}

Asupan energi siswa SMA Pembangunan Kota Padang 24.6\% lebih. Penelitian Sutrio 2017, dari 135 siswa sebanyak 43 siswa (31.9\%) memiliki asupan energi yang lebih (Sutrio, 2017). Asupan energi yang dikonsumsi siswa SMA Pembangunan Kota Padang rata-rata 1959 kkal, asupan minumum 989 kkal dan asupan maksimum $3439.7 \mathrm{kkal}$. kebutuhan energi seharusnya anak usia 13-15 tahun 2400 kkal untuk laki-laki dan 2050 kkal untuk perempuan, anak usia 16-18 tahun 2650 kkal untuk laki-laki dan 2100 kkal untuk perempuan. (Peraturan Menteri Kesehatan Republik Indonesia No 28 Tahun 2019, 2019).

Berdasarkan penelitian ini dapat menunjukkan bahwa rata-rata asupan energi responden tidak sesuai dengan kebutuhan seharusnya. Soekirman 2006 mengatakan konsumsi energi yang melebihi kecukupan dapat mengakibatkan kenaikan berat badan dan apabila terus berlanjut maka akan menyebabkan kegemukan dan resiko penyakit degeneratif (Soekirman, 2006).

Asupan lemak siswa SMA Pembangunan Kota Padang 17.5\% melebihi kebutuhan. Hasil penelitian Wulandari 2017 menyebutkan bahwa 30\% asupan lemak remaja SMA diatas kebutuhan, dan menunjukkan bahwa asupan lemak rata-rata yang dikonsumsi responden $70.01 \mathrm{gr}$, asupan minimum $25.60 \mathrm{gr}$ dan asupan maksimum $119.40 \mathrm{gr}$ (D. T. Wulandari \& Mardiyati, 2017). Hasil penelitian ini menunjukkan bahwa asupan lemak yang dikonsumsi siswa SMA Pembangunan Kota Padang rata-rata 57.67 $\mathrm{gr}$, asupan minimum $22.2 \mathrm{gr}$ dan asupan maksimum 108.1 gr. Kebutuhan lemak seharusnya anak usia 13-15 tahun $80 \mathrm{gr}$ untuk laki-laki dan $70 \mathrm{gr}$ untuk perempuan. Anak usia 16-18 tahun 85 gr untuk laki-laki dan $70 \mathrm{gr}$ untuk perempuan (Peraturan Menteri Kesehatan Republik Indonesia No 28 Tahun 2019, 2019).

Berdasarkan hasil penelitian ini, ratarata asupan lemak responden tidak sesuai dengan kebutuhan seharusnya. Wulandari 2017 juga mengatakan asupan lemak yang melebihi kebutuhan dalam jangka waktu lama dapat memicu timbulnya masalah gizi lebih (D. T. Wulandari \& Mardiyati, 2017).
Aktivitas
fisik
siswa
SMA

Pembangunan Kota Padang 36.8\% tidak aktif. Sejalan dengan penelitian Sutrio 2017 yaitu $37 \%$ responden memiliki aktivitas fisik tidak aktif. Aktifitas fisik atau adalah sesuatu yang menggunakan tenaga atau energi untuk melakukan berbagai kegiatan fisik seperti berjalan, berlari, olahraga, dan lain-lain (Sutrio, 2017). Responden cenderung lebih banyak melakukan aktivitas fisik intensitas sedang, seperti jalan cepat, berjalan, bermain voly dan berenang. Responden yang aktivitas fisik tidak aktif, cenderung lebih banyak duduk, dan jarang melakukan olahraga, aktivitas fisik yang dilakukan hanya aktivitas saat disekolah. Aktivitas fisik intensitas tinggi banyak dilakukan oleh responden laki-laki seperti berlari, fitness dan bermain sepak bola.

Pengetahuan gizi siswa SMA Pembangunan Kota Padang $28.1 \%$ cukup, artinya lebih dari separuh pengetahuan gizi responden sudah baik. Hal ini sejalan dengan penelitian Sutrio 2017 yaitu lebih dari separuh responden memiliki pengetahuan gizi yang baik (Sutrio, 2017). Menurut Pakar Gizi Indonesia tahun 2017 Pengetahuan yang kurang tentang makanan sehat dan gizi seimbang membuat masyarakat cenderung memilih makanan sesuai dengan selera, sosial ekonomi, dan trend sosial yang terjadi di masyarakat (Pakar Gizi Indonesia, 2017).

$$
\text { Kualitas tidur siswa SMA }
$$

Pembangunan Kota Padang lebih dari separuh buruk, yaitu sebesar $57.9 \%$. Hal ini sejalan dengan penelitian Agustin 2012, yaitu jenis kualitas tidur terbanyak terdapat pada kualitas tidur yang buruk (Agustin, 2012). siswa yang memiliki kualitas tidur yang buruk banyak terdapat pada siswa yang memiliki durasi tidur <.7 jam sehari, memiliki gangguan tidur seperti terbangun pada tengah malam, merasa tidak nyaman, batuk, harus bangun untuk ke kamar mandi, merasa kedinginan/ kepanasan, dan mengalami mimpi buruk.

Gizi lebih di SMA Pembangunan Kota Padang sebesar 28.1\%. terdiri dari 13 orang siswa perempuan (35.1\%), 3 orang siswa laki-laki $(15.0 \%)$ dan 12 orang siswa 
umur 16-18 tahun (26.1\%), 4 orang siswa umur 13-15 tahun (36.4\%). Data Dinas Kesehatan Kota Padang tahun 2017 menunjukkan bahwa status gizi remaja berdasarkan indeks IMT/U diperoleh data prevalensi overweight dan obesitas tertinggi terdapat di SMA Pembangunan Kota Padang yaitu sebesar 22.52\% (DKK, 2018). Hal ini menunjukkan bahwa gizi lebih di SMA mengalami peningkatan di tahun 2019.

Tabel 2. Hubungan asupan energi, asupan lemak, aktivitas fisik, pengetahuan dan kualitas tidur dengan kejadian gizi lebih SMA

\begin{tabular}{|c|c|c|c|c|c|c|c|}
\hline \multirow{3}{*}{ Variabel } & \multicolumn{4}{|c|}{ Kejadian Gizi Lebih } & \multirow{2}{*}{\multicolumn{2}{|c|}{ Total }} & \multirow{3}{*}{$p$ value } \\
\hline & \multicolumn{2}{|c|}{ Gizi Lebih } & \multicolumn{2}{|c|}{ Tidak Gizi Lebih } & & & \\
\hline & $\mathbf{n}$ & $\%$ & $\mathbf{n}$ & $\%$ & $\mathbf{n}$ & $\%$ & \\
\hline Asupan Energi & & & & & & & 0,001 \\
\hline Lebih & 9 & 64,3 & 5 & 35,7 & 14 & 100 & \\
\hline Cukup & 7 & 16,3 & 36 & 83,7 & 43 & 100 & \\
\hline Asupan Lemak & & & & & & & 0,003 \\
\hline Lebih & 7 & 70,0 & 3 & 30,0 & 10 & 100 & \\
\hline cukup & 9 & 19,1 & 38 & 80,9 & 47 & 100 & \\
\hline Aktivitas Fisik & & & & & & & \\
\hline Tidak aktif & 10 & 47,6 & 11 & 52,4 & 21 & 100 & 0,012 \\
\hline $\begin{array}{l}\text { Aktif } \\
\text { Pengetahuan }\end{array}$ & 6 & 16,7 & 30 & 83,3 & 36 & 100 & \\
\hline Cukup & 8 & 50,0 & 8 & 50,0 & 16 & 100 & 0,046 \\
\hline $\begin{array}{l}\text { Baik } \\
\text { Kualitas Tidur }\end{array}$ & 8 & 19,5 & 33 & 80,5 & 41 & 100 & \\
\hline Buruk & 12 & 36,4 & 21 & 63,6 & 33 & 100 & 0,102 \\
\hline Baik & 4 & 16,7 & 20 & 83,3 & 24 & 100 & \\
\hline
\end{tabular}

Hasil analisis uji statistik chi square dengan nilai $p=0.001$ yang menunjukkan terdapat hubungan yang bermakna antara asupan energi dengan kejadian gizi lebih pada siswa SMA, $(\mathrm{p}<0.05)$ (Tabel 2). Hasil penelitian ini sesuai dengan penelitian Sutrio 2017 menunjukkan bahwa ada hubungan yang signifikan antara asupan energi dengan status gizi siswa SMA (Sutrio, 2017). Sejalan dengan penelitian Dewi 2017 yaitu terdapat hubungan yang bermakna antara asupan energi dengan status gizi lebih (Dewi, 2017), dan sejalan dengan penelitian Qamariyah 2018 yaitu terdapat hubungan asupan energi dengan status gizi (Qamariyah \& Nindya, 2018). Gibney et al. (2009) menyatakan bahwa gizi lebih merupakan hasil dari ketidakseimbangan asupan energi jangka panjang di mana asupan energi melebihi energi yang keluar (Gibney et al., 2009).

Smith menyatakan bahwa remaja pada umumnya lebih memilih dan menyukai makanan dengan kadar kalori tinggi yang berasal dari karbohidrat. Hal tersebut mendukung terjadinya gizi lebih pada remaja dikarenakan tingginya konsumsi karbohidrat yang menyebabkan meningkatnya asupan kalori dalam tubuh (Smith, 2006). Penelitian ini dapat menyimpulkan bahwa asupan energi merupakan penyebab kejadian gizi lebih pada remaja SMA. Hal ini sesuai dengan teori yang menyebutkan bahwa asupan zat gizi merupakan faktor penyebab langsung yang akan mempengaruhi status gizi.

Hasil analisis uji statistik chi square dengan nilai $p=0.003$ yang menunjukkan terdapat hubungan yang bermakna antara asupan lemak dengan kejadian gizi lebih pada siswa SMA, $(p<0.05)$. Hal ini sesuai dengan penelitian Ernawati 2019 yaitu terdapat hubungan yang bermakna antara asupan lemak dengan gizi lebih, dan asupan lemak anak yang tinggal di kota lebih tinggi daripada di pedesaan (Ernawati et al., 2019). Sejalan dengan penelitian Dewi 2017 yaitu terdapat hubungan yang signifikan antara asupan lemak dengan status gizi lebih (Dewi, 2017), dan 
penelitian Nurani 2005 yang menunjukkan terdapat hubungan asupan lemak dengan IMT (Indeks Massa Tubuh) dengan remaja (Nurani, 2005).

Berdasarkan hasil wawancara dengan responden menggunakan SQ FFQ diketahui bahwa bahan makanan tinggi lemak yang sering dikonsumsi responden status gizi lebih adalah minyak goreng, daging ayam, mentega, telur ayam dan makanan yang menggunakan santan serta jajanan kantin seperti coklat, tahu dan tempe goreng. Selain bahan makanan tinggi lemak, diketahui responden jarang mengkonsumsi buah dan sayur.Dalam 1 minggu responden hanya mengkonsumsi buah dan sayur tesebut hanya $2 x$ saja dalam 1 minggu tersebut, Buah yang dikonsumsi responden gizi lebih hanya pisang, semangka, pepaya dan jeruk manis. Sayuran yang dikonsumsi seperti wortel, bayam, kangkung, dan buncis. Jenis bahan makanan yang dikonsumsi responden tidak gizi lebih cenderung sama dengan responden yang mengalami gizi lebih, tetapi dari segi kuantitas dan frekuensi makan yang dikonsumsi responden berbeda.

Penelitian ini dapat menyimpulkan bahwa asupan lemak merupakan penyebab kejadian gizi lebih pada remaja SMA. Hal ini sesuai dengan teori yang menyebutkan bahwa asupan zat gizi merupakan faktor penyebab langsung yang akan mempengaruhi status gizi.

Hasil analisis uji statistik chi square dengan nilai $p=0.017$ yang menunjukkan terdapat hubungan yang bermakna antara aktivitas fisik dengan kejadian gizi lebih pada siswa SMA, $(p<0.05)$. Hal ini sesuai dengan penelitian Nugroho 2016 yang menunjukkan terdapat hubungan yang bermakna antara aktifitas fisik dengan IMT (Indeks Massa Tubuh) (Nugroho et al., 2016). Sejalan dengan penelitian Dewi 2017 yaitu terdapat hubungan yang signifikan antara aktivitas fisik dengan status gizi lebih (Dewi, 2017), dan sejalan dengan penelitian Praditasari 2018 yaitu terdapat hubungan aktivitas fisik dengan kegemukan pada remaja (Praditasari \& Sumarmi, 2018).

Aktivitas fisik yang kurang menyebabkan banyak energi yang tersimpan sebagai lemak, sehingga orang- orang yang kurang melakukan aktivitas cenderung menjadi gemuk. Hal ini menjelaskan bahwa tingkat aktivitas fisik berkontribusi terhadap kejadian berat badan berlebih (Nugroho et al., 2016). Oleh karena itu, untuk mencegah kelebihan berat badan dan obesitas pada remaja perlu dilakukan aktivitas fisik yang sesuai, aman dan efektif. Seperti dengan berolahraga teratur dan terkontrol, karena akan membantu memelihara berat badan yang optimal.

Hasil analisis uji statistik chi square dengan nilai $p=0.046$ yang menunjukkan terdapat hubungan yang bermakna antara pengetahuan gizi dengan kejadian gizi lebih pada siswa SMA, $(p<0.05)$. Hal ini sesuai dengan penelitian Florence 2017 yang menunjukkan bahwa terdapat hubungan yang bermakna antara pengetahuan gizi dengan status gizi (Florence, 2017). Sejalan dengan penelitian Sutrio 2017 yang menunjukkan terdapat hubungan yang signifikan antara pengetahuan gizi dengan status gizi (Sutrio, 2017), dan sejalan dengan penelitian Alfyan 2010 yaitu terdapat hubungan antara pengetahuan gizi dengan status gizi remaja SMA (Alfyan, 2010).

Hubungan antara pengetahuan dengan status gizi terlihat bahwa semakin rendah pengetahuan remaja tentang gizi akan semakin besar kemungkinan untuk memiliki status gizi lebih. Berdasarkan hasil penelitian, responden cenderung memiliki pengetahuan gizi yang kurang tentang zat gizi, makanan yang sehat dan gizi seimbang. Hal ini akan mempengaruhi pemilihan responden terhadap makanan yang akan dikonsumsi. Hal ini juga berkaitan dengan teori yang mengatakan bahwa tingkat pengetahuan gizi seseorang berpengaruh terhadap sikap dan perilaku dalam memilih makanan yang menentukan mudah tidaknya seseorang memahami manfaat kandungan gizi dari makanan yang dikonsumsi (Sediaoetama, 2004).

Hasil analisis uji statistik chi square dengan nilai $p=0.102$ yang menunjukkan tidak ada hubungan yang bermakna antara kualitas tidur dengan kejadian gizi lebih pada siswa SMA, $(p>0.05)$. Hasil penelitian ini tidak sejalan dengan penelitian Ryandra 2016 yang menunjukkan bahwa terdapat hubungan yang signifikan antara kualitas 
tidur dengan berat badan berlebih (Ryandra, 2016). Jadi penelitian ini Ryandra mengatakan bahwa kualitas tidur sangat berpengaruh terhadap kejadian berat badan berlebih ini. Namun hasil penelitian ini sesuai dengan penelitian Fikri 2016 yang menunjukkan bahwa tidak ada hubungan yang bermakna antara kualitas tidur dengan kejadian gizi lebih (Fikri \& Husna, 2016). Sesuai dengan penelitian Tasya 2017 yaitu tidak terdapat hubungan yang bermakna antara kualitas tidur dan perubahan berat badan (Tasya \& Tirtayasa, 2017), dan sejalan dengan penelitian Ganakin 2017 yaitu tidak terdapat hubungan antara kualitas tidur dengan status gizi lebih (Ganakin, 2017).

Namun, berdasarkan hasil penelitian ini ada kecenderungan bahwa siswa yang mengalami gizi lebih banyak terdapat pada siswa yang memiliki kualitas tidur yang buruk. Penelitian Marfuah tahun 2015 mengatakan bahwa kejadian gizi lebih banyak terdapat pada siswa yang memiliki kualitas tidur yang buruk, semakin pendek durasi tidur seseorang maka semakin tinggi resiko mengalami gizi lebih (Marfuah, 2015). Durasi tidur yang pendek akan meningkatkan rasa lapar dan terjadi peningkatan rasa untuk makan, hal ini akan meningkatkan asupan energi. Durasi tidur yang pendek juga akan menyebabkan terjadinya perubahan termoregulasi dan meningkatkan kelelahan, hal ini akan menurunkan energi expenditure. Tingginya asupan energi yang tidak diimbangi dengan energi expenditure akan menyebabkan terjadinya gizi lebih (Marfuah, 2015).

Tidur (2-4 jam sehari) dapat mengakibatkan kehilangan $18 \%$ leptin dan meningkatkan $28 \%$ grelin yang dapat menambah nafsu makan kira-kira 23-24\%. Leptin adalah protein hormon yang diproduksi jaringan lemak yang berfungsi mengendalikan cadangan lemak dan memengaruhi nafsu makan, sedangkan grelin adalah hormon yang dapat memengaruhi rasa lapar dan kenyang. Apabila leptin menurun dan grelin meningkat dapat meningkatkan rasa lapar dan membuat metabolisme melambat serta kemampuan membakar lemak dalam tubuh berkurang (Septiana \& Irwanto, 2018).

\section{KESIMPULAN}

Terdapat hubungan antara asupan energi,asupan lemak,aktifitas fisik dan pengetahuan dengan kejadian gizi lebih pada siswa SMA ( $p$ value $<0,05$ ) sedangkan untuk kualitas tidur tidak terdapatnya hubungan dengan kejadian gizi lebih pada siswa SMA.

\section{REFERENSI}

Afrilia, D. A., \& Festilia, S. (2018). Hubungan Pola Makan dan Aktivitas Fisik terhadap Status Gizi di Siswa SMP Al Azhar Pontianak. Pontianak Nutrition Journal (PNJ), 01(01), 12.

Agustin. (2012). Faktor-faktor yang mempengaruhi kualitas tidur pada pekerja shift di PT Krakatau Tirta Industri Cilegon. Universitas Indonesia.

Alfyan, M. T. (2010). Hubungan Pengetahuan Gizi Dengan Status Gizi Siswa Di Sma Harapan 1 Medan. USU.

Almatsier, S. (2013). Prinsip Dasar IImu Gizi (R. Pradana (ed.); 9th ed.). PT Gramedia Pustaka Utama.

Dewi, P. L. P. (2017). Hubungan Pengetahuan Gizi, Aktivitas Fisik dan Asupan Energi, Asupan Lemak dengan Kejadian Obesitas pada Remaja SMP. Nutrition College, 6(3).

DKK. (2018). Rekapitulasi Hasil Penjaringan Kesehatan Murid SMA se Kota Padang Tahun 2017.

Ermona, N. D. N., \& Wirjatmadi, B. (2018). Hubungan Aktivitas Fisik Dan Asupan Gizi Dengan Status Gizi Lebih Pada Anak Usia Sekolah Dasar Di Sdn Ketabang 1 Kota Surabaya Tahun 2017. SA License, 98.

Ernawati, F., Pusparini, Arifin, A. Y., \& Prihatini, M. (2019). Hubungan Asupan Lemak Dengan Status Gizi Anak Usia 6 Bulan-12 Tahun Di Indonesia. Penelitian Gizi Dan Makanan, 42(1).

Fikri, H. K., \& Husna, C. A. (2016). Hubungan Kualitas Tidur Dengan Obesitas Pada Anak Sekolah Dasar (Sd) Negeri Di Desa Kampung Jawa Lama Dan Lancang Garam Kota Lhokseumawe. Averrous, 4(1).

Florence, A. G. (2017). Hubungan Pengetahuan Gizi Dan Pola Konsumsi Dengan Status Gizi Pada Mahasiswa Tpb Sekolah Bisnis Dan Manajemen 
Institut Teknologi Bandung.

Ganakin, S. V. (2017). Hubungan Kualitas Tidur dengan Kondisi Obesitas pada Mahasiswa Fakultas Kedokteran UKWMS.

Gibney, M. J., Margetts, B. M., Kearney, J. M., \& Arab, L. (2009). Gizi Kesehatan Masyarakat (S. S. Nuning Zuni Astuti (ed.); 1st ed.). Buku Kedokteran EGC.

Marfuah, D. (2015). Kualitas Tidur Hubungannya dengan Obesitas pada Anak Sekolah Dasar di Yogyakarta. Profesi, 12.

Nugroho, K., Mulyadi, \& Masi, G. N. M. (2016). Hubungan Aktivitas Fisik Dan Pola Makan Dengan Perubahan Indeks Massa Tubuh Pada Mahasiswa Semester 2 Programstudi IImu Keperawatan Fakultas Kedokteran. E Jurnal Keperawatan, 4(2).

Nurani, G. S. (2005). Analisis Hubungan Asupan Energi, Protein, Lemak, Karbohidrat Dan Serat Dengan Indeks Massa Tubuh CDC pada Siswa SLTA. Eprints Undip.

Pakar Gizi Indonesia. (2017). IImu Gizi Teori dan Aplikasi (Hadinsyah \& I. dewa N. Supariasa (eds.)). Buku Kedokteran EGC.

Peraturan Menteri Kesehatan Republik Indonesia No 28 Tahun 2019. (2019). Angka Kecukupan Gizi Yang Dianjurkan Untuk Masyarakat Indonesia.

Praditasari, J. A., \& Sumarmi, S. (2018). Asupan Lemak, Aktivitas Fisik Dan Kegemukan Pada Remaja Putri Di SMP Bima Insani Surabaya. 13(2), 120.

Putra, T. E., Astiti, D., \& Syamsiatun, N. H. (2017). hubungan antara durasi dan kualitas tidur dengan Overweight pada mahasiswa universitas alma ata Yogyakarta. Jurnal Gizi Dan Dietetik, 1.

Qamariyah, B., \& Nindya, T. S. (2018). Hubungan Antara Asupan Energi, Zat Gizi Makro dan Total Energy Expenditure dengan Status Gizi Anak Sekolah Dasar. SA License, 2(1).

Riskesdas. (2013). Badan Penelitian dan Pengembangan Kesehatan Kementerian RI Tahun 2013.

Riskesdas. (2018). Badan Penelitian dan Pengembangan

Kesehatan
Kementerian RI Tahun 2018.

Ryandra, Y. (2016). Hubungan Kualitas Tidur dengan Indeks Massa Tubuh Berlebih pada Mahasiswa Fakultas Kedokteran Universitas Muhammadiyah Malang. Umm Institutional Repository.

Sediaoetama, A. D. (2004). IImu Gizi untuk Mahasiswa dan Profesi (5th ed.). Dian Rakyat.

Septiana, P., \& Irwanto. (2018). Hubungan Durasi Tidur dengan Kejadian Obsitas pada Anak Usia 3-8 Tahun. Global Medical and Health Communication, 63.

Smith, A. M. (2006). Contemporary Nutrition (7th ed.). McGraw Hill Companies.

Soekirman. (2006). Hidup Sehat Gizi Seimbang Dalam Siklus Kehidupan Manusia. PT Gramedia Pustaka Utama.

Soraya, D., Sukandar, D., \& Sinaga, T. (2017). Hubungan pengetahuan gizi, tingkat kecukupan zat gizi, dan aktivitas fisik dengan status gizi pada guru SMP. Jurnal Gizi Indonesia, 6(1), 30.

Sutrio. (2017). Hubungan Asupan Energi, Pengetahuan Gizi dan Aktivitas Fisik terhadap Status Gizi Siswa SMA Global Madani Kota Bandar Lampung Tahun 2016. Jurnal Kesehatan Holistik, 11(1), 29.

Tasya, N. S., \& Tirtayasa, K. (2017). Hubungan Antara Kualitas Tidur Dan Perubahan Berat Badan Pada Mahasiswa Perempuan Program Studi Kedokteran Umum Tahun Pertama Di Universitas Udayana. Intisari Sains Medis, 8(2).

Wulandari, D. T., \& Mardiyati, N. L. (2017). Hubungan Antara Asupan Karbohidrat dan Lemak dengan Kejadian Overweight pada Remaja di SMA Muhammadiyah 4 Kartasura Kabupaten Sukoharjo. Jurnal Riset Kesehatan, 9(1), 55.

Wulandari, N. W. M., Muniroh, L., \& Nindya, T. S. (2015). Asupan Energi dan Aktivitas Fisik berhubungan dengan ZScore IMT/U Anak Sekolah Dasar di Daerah Perdesaan. Media Gizi Indonesia, 10(1), 55.

Wulandari, S., Lestari, H., \& Fachlevy, A. F. 
Jurnal Kesehatan Perintis (Perintis's Health Journal) 8 (1) 2021: 45-53

(2016). Faktor faktor yang

berhubungan dengan kejadian

obesitas pada remaja SMA 4 Kendari tahun 2016. 2. 